\title{
DULEBA Szabolcs
}

\section{A KÖZÉP. ÉS FELSÖ VEZETÖI DÖNTÉSEKET TÁMOGATÓ AHP-MÓDSZER, ÉS ALKALMAZÁSA LOGISZTIKAI SZOLGÁLTATÓK KIVÁLASZTÁSÁRA}

A vállalatok és intézmények közép-, illetve felső vezetői gyakran szembesülnek komplex, többtényezős döntési problémákkal. Az AHP-t (Analitic Hierarchy Process) néhány multinacionális vállalat elsősorban a „make or buy” - vagyis a saját tevékenység elvégzése, illetve külső cég megbízása - döntésekre (Szegedi, 2003) alkalmazza, de gyakran használják partnercégek kiválasztására is. A szerző az utóbbihoz ad egy lehetséges kritériumrendszert, nevezetesen annak elősegítésére, hogy hogyan válasszák ki az optimális logisztikai szállítmányozót, azaz 3PL (Bokor, 2004) típusú partnereket (olyan logisztikai szolgáltatók, melyek megbízói más szektor vállalatai). A cikk célja e metódus előnyeinek és hátrányainak számbavétele, valamint alkalmazásának bemutatása egy valós gyakorlati problémán keresztül, mely nóvumnak számít a hazai szakirodalomban.

Az AHP-módszert eredetileg 1977-ben Thomas L. Saaty fejlesztette ki, majd Liu és Akash továbbfejlesztette 1999-ben. A gyakorlatban jelenleg is használt formáját 2001-ben érte el, Saaty és Vargas munkája nyomán. Ezután használata igen széles körben elterjedt, az Európai Unió SULOGTRA nevű kutatási programja is felhasználta logisztikai szcenáriók megalkotására a 2000-2010-es időszakra vonatkozóan. (A SULOGTRA projektben több mint 400 uniós logisztikai vezetôt kérdeztek az általuk legfontosabbnak ítélt logisztikai tendenciákról, válaszaikat pedig az AHPvel elemezték.)

Az AHP létrehozását az a kérdés motiválta, hogy a vezetôi döntéshozatalban milyen módon lehetne érvényre juttatni a szubjektív és az objektív elemek szintézisét. Emellett a kvantitatív és a kvalitatív módszerek integrálására is igény mutatkozott, ezekre próbált választ adni a Saaty által konstruált metódus.

Ez a metódus egy komprehenzív, logikai és strukturális rendszer, amely a döntési probléma jobb megértését biztosítja azáltal, hogy komponenseire bontja a problémát, majd hierarchikus struktúrába rendezi azt. Az AHP különösen alkalmas olyan problémák megoldására, amelyek esetében nehezen kvantifikálható döntési elemek összehasonlítására van szükség. Ezen elemek páronkénti összehasonlítása biztosíthatja a vezető számára az úgynevezett „trade-off” célok közötti választást, vagyis két vagy több, egymásnak ellentmondó cél közül a fontosabb meghatározását.

Alapvetően három elv alkalmazása történik:

- a döntési probléma dekomponálása,

- az elemek összehasonlító értékelése,

- a megállapított prioritások szintézise.

$\mathrm{Az}$ első alapelv révén elkülöníthetővé válnak a komplex probléma elemei, majd klaszterek és alklaszterek formájában alá-fölérendeltségi struktúrába rendezhetők. (A cikk második részében ezt példával illusztráljuk.) A második alapelv a kiválasztandó elemek minden lehetséges párjának összehasonlítását jelenti a Saaty-féle skála alapján (1. táblázat). A skála 1-től 9-ig osztályozza a két elemet, ahol az 1-es a két komponens adott vezető számára ugyanolyan fontosságát jelenti, míg a 9-es az egyik komponens abszolút dominanciáját jelenti fontosság tekintetében. A harmadik, és utolsó alapelv a klasztereken belüli prioritásokat összegzi, és létrehoz egy, a probléma egészét jellemző tényezőt, amely valós segítséget nyújt a döntéshozónak. 
A tényezők összehasonlításainak skálája

1. táblázat

\begin{tabular}{|l|c|}
\hline Szöveges meghatározás & Numerikus érték \\
\hline Ugyanolyan fontosságú & 1 \\
\hline Mérsékelten fontosabb, enyhén preferált & 3 \\
\hline Lényegesen fontosabb, erősen preferált & 5 \\
\hline Sokkal fontosabb, igen erősen preferált & 7 \\
\hline Abszolút fontosabb & 9 \\
\hline A skála köztes értékei & $2,4,6,8$ \\
\hline
\end{tabular}

A következőkben olvasható alkalmazás remélhetőleg segíti majd a folyamat teljes megértését. A gyakorlatban műszaki és közgazdasági területen egyaránt használják a módszert a következő előnyök miatt:

- viszonylag egyszerű az alkalmazása,

- kvantitatív és kvalitatív tényezők egyaránt szerepelhetnek az eljárásban,

- a szintézis figyelembe veszi az összes preferenciát,

- önellenőrző lépést is tartalmaz (ennek bemutatása a későbbiekben).

Fontosnak tartom megemlíteni a hátrányokat is:

- Szubjektivitás. A döntési folyamat sikerességében meghatározó a döntéshozó preferenciáinak azonosítása, melyek nem minden esetben állapíthatóak meg teljes körűen. A korlátozott racionalitás gyengítheti a végső döntés helyességét.

- Konzisztencia követelmény. A módszer feltételezi, hogy a megkérdezett személy több táblázat kitöltésére konzisztensen képes, preferenciái tranzitív módon is megfelelnek egymásnak. A gyakorlatban természetesen ez nem mindig van így. Ezért nagyon lényeges eleme a modellnek az inkonzisztencia hányados, amely megmutatja, hogy a megkérdezett nem következetesen töltötte ki a táblázatot. Ebben az esetben újra kell kezdeni a folyamatot. Az ebből adódó hátrány viszont a plusz energia és költség, amely sorozatos nem következetes kitöltésnél jelentős is lehet. (Az inkonzisztencia hányadost a mátrix legnagyobb sajátértéknek a mátrix rendjével, illetve ezek korrekcióival való osztás által kaphatjuk meg.)

Az AHP alábbiakban bemutatandó alkalmazása egy olyan felsővezetői problémára nyújthat megoldást, amely igen gyakran merül föl hazánk versenyszektorban működő vállalatainál. A megfelelő logisztikai szolgáltató kiválasztása stratégiai jelentőségű, hosszú távon is versenyképességet befolyásoló tényező lehet (Szegedi, 2003). Természetesen nem állítható, hogy az
AHP az egyetlen lehetséges módszer a vállalatvezetők véleményének a szintetizálására (alkalmazható módszer lehet például még a perceptuális megközelítés, valamint más kvantifikált metódusok), azonban ez a multikritériumos döntési helyzet gyakorlati és elméleti szempontból egyaránt megfelel célunknak.

\section{A logisztikai szolgáltatók kiválasztásának dilemmája}

Az outsourcing (kiszervezés) egyre gyakoribb alkalmazása rámutat arra, hogy egyre inkább növekszik a vállalati kereslet a logisztikai szolgáltatók iránt. Ez a tendencia a nyugat-európai országokban már évtizedek óta érzékelheto”, azonban a '90-es évek közepétől már Magyarországon is tetten érhető. Ez a trend növeli meg az úgynevezett 3 PL szolgáltatók piaci fontosságát. A 3 PL - Third Party Logistic Service Providers szereplők logisztikai tevékenységeket végeznek a megbízóik számára. Alkalmazásuk nagyobb rugalmasságot, a működési hatékonyság fokozását, növekvő vevőkiszolgálási szintet, csökkenő költségeket, valamint hatékonyabb koncentrálást biztosít a cég alapvető kompetenciáira.

A partner 3 PL kiválasztása, mivel nagyon sok tényező figyelembevételével kell a döntést meghozni, nagy dilemmát jelenthet a döntéshozóknak. Ezen túlmenően, a probléma tartalmaz mennyiségi és minőségi elemeket egyaránt. A tényezők között pedig sok csak egy másik kárára valósulhat meg (trade-off) gondoljunk például a növekvő vevőelégedettség költségnövelő hatására. (Bár ez klasszikusnak számító trade-off pár, a modern menedzsment-tudomány néhány esetben már nem fogadja el.) A fenti jellemzők indokolttá teszik az AHP módszer használatát. Ez a következő négy lépésben történhet (Saaty, 1990):

1) A döntési probléma pontos azonosítása és a hierarchia megalkotása.

2) Elvégezni a döntési elemek közötti páronkénti összehasonlítást.

3) A kritériumok végső súlyának kiszámítása.

4) Megalkotni a végleges kiválasztási folyamatot.

\section{Lépés}

A problémánál két szintet különböztethetünk meg. A hierarchiában felül elhelyezkedő szint javaslatom szerint 5 kritériumból célszerű, hogy álljon. Lehetséges más csoportosítás, valamint más értékelési szempont figyelembevétele is, ezt a döntéshozók korrigálhatják. A javasolt elsődleges tényezők: szállítás, raktározás és készletezés, szolgáltatási szint és minőség, költségek szintje, valamint az alkalmazott technológia. 
Az első két kritérium magába foglalja a logisztikai alaptevékenységek (Rakodás, Szállítás, Tárolás) mindegyikét, a harmadik ezek minőségi követelményeit tartalmazza, a negyedik a gazdasági, vagyis a költségvonzatukat, az ötödik pedig az alkalmazott múszaki, technológiai jellemzőket tömöríti.

A második szinten ezeknek a kritériumoknak az alklaszterei helyezkednek el, vagyis azok a tényezők, amelyek leginkább befolyásolják az öt kritérium megfelelőségét a döntéshozó számára. A szállításnál: időre szállítás(SZ1), könyvelési és számlázási pontosság(SZ2), illetve a járművek állapota(SZ3), valamint a fel- és lerakodás(SZ4). A raktározás és készletezésnél: rendelésfeldolgozás folyamatának jellemzői(R1), rendelések teljesítésének pontossága(R2), időben történő betárolás(R3), időben történő kitárolás(R4), a készletezés helyes menedzselése(R5). Szolgáltatási szint és minőség: eszközök elérhetősége(M1), problémamegoldó képesség(M2), a szállítási és raktározási szolgáltatás minősége(M3), a szolgáltató pénzügyi stabilitása(M4), hírnév(M5), valamint a globális működésre való alkalmasság(M6). A költségek: a szállítási egységre jutó (fajlagos) költség(K1), tárolási egységre jutó raktárköltség(K2), szolgáltatási költség(K3), valamint az alkalmazással járó költségcsökkenés(K4). Az alkalmazott technológia: nyomkövető rendszerek alkalmazása (tracking and tracing)(T1), elektronikus adatcsere (EDI)(T2), internet és e-kereskedelem(T3), folyamatfejlesztés(T4), illetve technológiafejlesztés(T5).

\section{Lépés}

A döntési tényezők páronkénti összehasonlításának elvégzése a lehetséges szolgáltatókra vonatkoztatva. A hierarchia felállítása után a döntési komponensek egymáshoz viszonyított fontosságának a megállapításához olyan kérdőívet kell készíteni, amely a döntéshozó(k) preferenciáira kérdez rá. Egy jellemző kérdés: Ön mennyivel értékeli jobbnak a szállítási teljesítmény tekintetében a B1-es szolgáltatót a B2-esnél az összes szállításra vonatkozó kritériumot figyelembe véve? A döntéshozó Saaty táblázata alapján numerikusan válaszol, amennyiben a B2-es szolgáltató számára jobb megítélés alá esik, mint a B1-es, a skála számainak reciprokával válaszol. Vagyis, ha a fenti kérdésre a válasz $1 / 7$, ez azt jelenti, hogy a megkérdezett személy sokkal jobbnak értékeli a B2-vel jelölt szolgáltatót a B1-esnél a szállítás szempontjából.

Ezeket a kérdéseket minden klaszter összes szolgáltató párjára fel kell tenni.

\section{Lépés}

Miután elvégeztük az összehasonlításokat, az adatokat mátrixokba tömörítjük, melyeknek sorai és oszlopai az egyes logisztikai szolgáltatók, a beírt számok pedig az egymáshoz viszonyított értékelésük adott logisztikai teljesítmény szempontjából. A mátrixok sajátértékeinek és sajátvektorainak kiszámítása alapján végezhetjük el az elsődleges kritériumok szerinti külön-külön értékelést. Mivel 5 elsődleges tényezőt azonosítottunk, ezért 5 mátrixot kell készítenünk, minden egyes tényezőre egyet-egyet.

\section{Lépés}

Az egyes kritériumok végső súlya alapján elvégezhetjük a 3PL vállalatok kiválasztási folyamatának utolsó fázisát. Ehhez szükség van még az elsődleges tényezők végső döntést befolyásoló súlyának kiszámítására, amelyet szintén páronkénti összehasonlítással kaphatunk meg. Ekkor a mátrixban a kritériumok egymáshoz képesti fontosságára kérdezünk rá. Például: a döntéshozó mennyivel tartja fontosabbnak a költségek tényezőjét a szállítási teljesítmény tényezőjénél? A válaszok a már fent ismertetett numerikus skála alapján lehetségesek itt is. Az így megkapott sajátvektor egyes értékei mutatják azt meg, hogy az egyes kritériumok százalékosan milyen fontossággal bírnak a döntéshozók számára. Ezeket az értékeket be kell szorozni az egyes kritériumok alapján összehasonlított szolgáltatói számokkal, így kijön az egyes szolgáltatók végső értékelése. Így elvégezhetjük a leginkább megfelelő logisztikai szolgáltató azonosítását. Az 1. ábra a komplex értékelést mutatja be.

A könnyebb megértés érdekében egy fiktív AHP analízist közlünk a fentebb ismertetett kritériumrendszert figyelembe véve. Tegyük fel, hogy egy cég vezetése az alábbi összehasonlítást végezte el 4 lehetséges logisztikai szolgáltató szállítási tevékenységének értékelése során (2. táblázat).

A bal oldali mátrixban a B1B2 elem azt mutatja, hogy a vezetőség a B1-es beszállítót szállítási tevékenység szempontjából enyhén preferálja a B2-eshez képest.

A relatív súlyok mátrixának egyes elemeit úgy kaptuk, hogy a baloldali mátrix elemeit elosztottuk oszlopösszegeikkel. Az ötödik oszlopban jelenik meg a szállításra vonatkozó sajátvektor(S.V.), melynek koordinátái az egyes beszállítók szállítási szempontból való minősítésének értékeit reprezentálják. A koordinátákat úgy kaphatjuk meg, hogy az adott sor számtani átlagát számoljuk ki.

A szállítás, mint elsődleges kritérium sajátvektora tehát a következő: $(0.446,0.308,0.2,0.046)$ A többi elsődleges kritérium lehetséges fiktív értékei: Raktározás: $(0.205,0.412,0.111,0.272)$ Költségek: $(0.33$, 0.202, 0.198, 0.27) Minőség:(0.2, 0.32, 0.211, 0.269) Technológia: $(0.155,0.221,0.405,0.219)$ 
A logisztikai szolgáltatók komplex értékelése AHP módszerrel

\section{Cél: a 3PL kiválasztása}
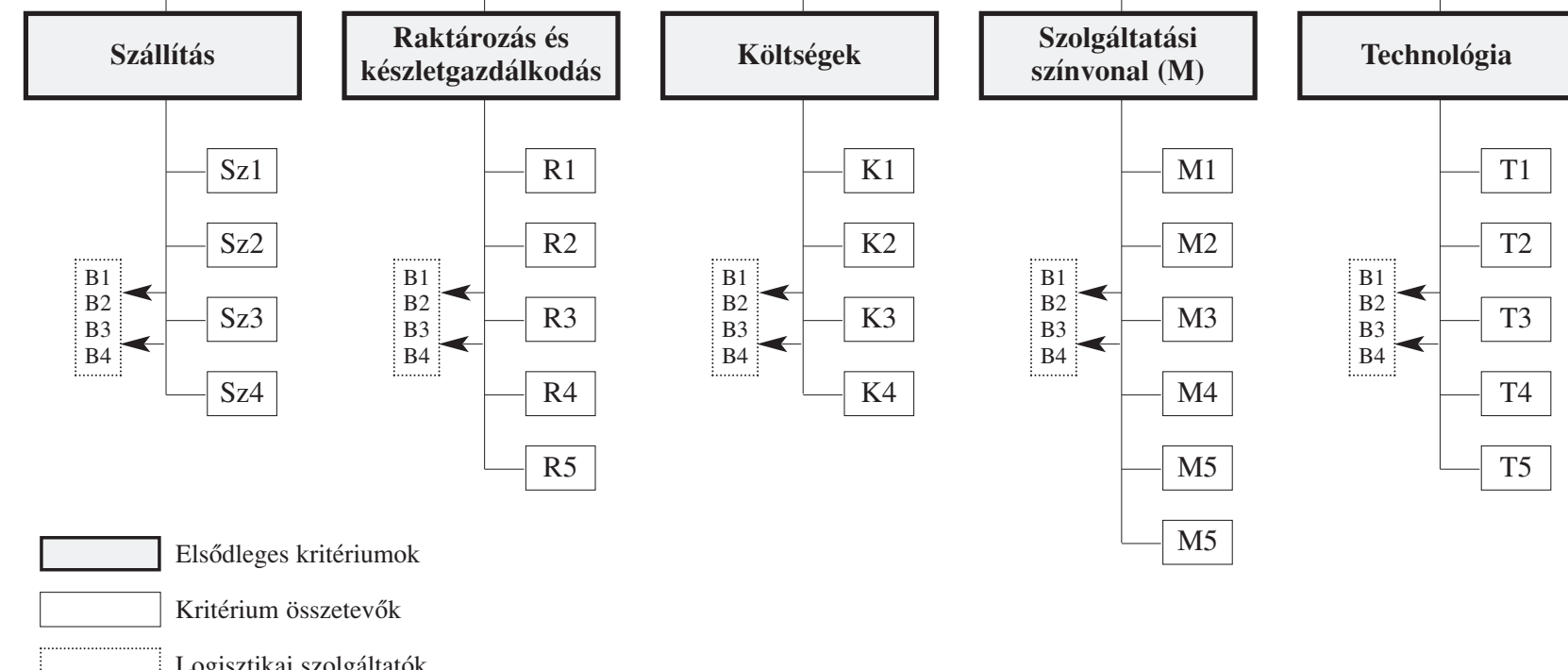

Elsődleges kritériumok

Kritérium összetevők

Logisztikai szolgáltatók

Forrás: Saját ábra

2. táblázat

A döntéshozó preferenciáiés az ebből képzett relatív súlyok

\begin{tabular}{|c|c|c|c|c|}
\hline \multicolumn{6}{|c|}{$\begin{array}{c}\text { A logisztikai szolgáltatók minősítése } \\
\text { a szállítás szempontjából }\end{array}$} \\
\hline & $\mathbf{B 1}$ & $\mathbf{B 2}$ & $\mathbf{B 3}$ & $\mathbf{B 4}$ \\
\hline B1 & 1 & 2 & 2 & 8 \\
\hline B2 & 0,5 & 1 & 2 & 7 \\
\hline B3 & 0,5 & 0,5 & 1 & 5 \\
\hline B4 & 0,125 & 0,143 & 0,2 & 1 \\
\hline & 2,125 & 3,643 & 5,2 & 21 \\
\hline
\end{tabular}

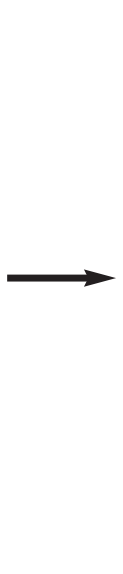

\begin{tabular}{|c|c|c|c|c|c|}
\hline \multicolumn{7}{|c|}{ A relatív súlyok mátrixa } \\
\hline B1 & 0,470 & 0,549 & 0,385 & 0,380 & 0,446 \\
\hline B2 & 0,235 & 0,274 & 0,385 & 0,330 & 0,308 \\
\hline B3 & 0,235 & 0,137 & 0,192 & 0,238 & 0,200 \\
\hline B4 & 0,059 & 0,039 & 0,038 & 0,048 & 0,046 \\
\hline & 1 & 1 & 1 & 1 & \\
\hline
\end{tabular}

Forrás: Saját táblázat

Szükség van még annak megállapítására, hogy az elsődleges kritériumoknak milyen fontosságot tulajdonít a vezetőség a megfelelő logisztikai szolgáltató partner kiválasztásában. Ezért el kell végeztetni ezen kritériumok páronkénti összehasonlítását is (3. táblázat).

A baloldali mátrix világos harmadát a vezetők töltötték ki preferenciáik alapján. Az SZ-K koordinátákkal megadható elem például azt fejezi ki, hogy a veze- tők a szállítási tevékenységet alárendeltnek tekintik a költség kritériumával szemben.(1/3)

Látható egyébként, hogy a példa cégnél a költségek kritériumát tekintik a legfontosabbnak, hiszen a költségek sorban a tényező minden más elsődleges tényezővel szemben preferált, leginkább a technológiával történt összevetésben (8-as, vagyis döntően nagyobb jelentőséggel bíró). 
Az elsődleges kritériumok egymáshoz viszonyítása és a képzett relatív súlyok

\begin{tabular}{|c|c|c|c|c|c|}
\hline & $\mathbf{S z}$ & $\mathbf{R}$ & $\mathbf{K}$ & $\mathbf{M}$ & $\mathbf{T}$ \\
\hline $\mathbf{S z}$ & 1 & 2 & 0,33 & 2 & 4 \\
\hline $\mathbf{R}$ & 0,5 & 1 & 0,25 & 2 & 3 \\
\hline $\mathbf{K}$ & 3 & 4 & 1 & 5 & 8 \\
\hline $\mathbf{M}$ & 0,5 & 0,5 & 0,2 & 1 & 2 \\
\hline $\mathbf{T}$ & 0,250 & 0,330 & 0,125 & 0,5 & 1 \\
\hline & 5,250 & 7,830 & 1,875 & 10,5 & 18 \\
\hline
\end{tabular}

\begin{tabular}{c|c|c|c|c|c|c|}
\hline & $\mathbf{S z}$ & $\mathbf{R}$ & $\mathbf{K}$ & $\mathbf{M}$ & $\mathbf{T}$ & $\mathbf{S . ~ V}$ \\
\hline $\mathbf{S z}$ & 0,4190 & 0,255 & 0,176 & 0,190 & 0,220 & 0,206 \\
\hline $\mathbf{R}$ & 0,095 & 0,128 & 0,130 & 0,190 & 0,167 & 0,142 \\
\hline $\mathbf{K}$ & 0,571 & 0,511 & 0,530 & 0,476 & 0,440 & 0,506 \\
\hline $\mathbf{M}$ & 0,095 & 0,064 & 0,107 & 0,095 & 0,110 & 0,094 \\
\hline $\mathbf{M}$ & 0,048 & 0,042 & 0,067 & 0,048 & 0,055 & 0,052 \\
\hline & 1 & 1 & 1 & 1 & 1 & \\
\hline
\end{tabular}

Forrás: Saját táblázat

A jobboldali mátrix utolsó oszlopában kialakuló sajátvektor - számítása ugyanaz, mint az előzőekben megmutatja mind az öt kritérium döntéshez kapcsolódó súlyát. A cél eléréséhez, vagyis a logisztikai szolgáltatók rangsorolásához, és a legmegfelelőbb kiválasztásához el kell még végezni az összesítést, amelyben az egyes 3PL-ek megfelelő sajátvektor koordinátáit beszorozzuk az adott elsődleges kritérium döntési súlyával, amit a kritériumok megfelelő sajátvektor koordinátája jelképez. Vagyis: B1: $0.206 * 0.446+$ $0.142 * 0.205+0.506 * 0.33+0.094 * 0.2+0.052 * 0.155=0$. 315 Ugyanezzel a számítási móddal a B2-re 0.265, a B3-ra 0.197, a B4-re pedig 0.223 adódik. Vegyük észre, hogy $\operatorname{SUM}(B)=1$

A módszerrel tehát meg lehet határozni a döntéshozók preferenciái szerint értékelt legmegfelelőbb logisztikai partnert (esetünkben B1-et).

\section{Összefoglalás}

A logisztikai kiszervezési döntések hazai gyakorlatában jelenleg még túlsúlyban vannak az úgynevezett „soft” döntési kritériumok. Ezek közé tartozik például a bizalom alapján való partnerválasztás, vagy a goodwill, jó hírnév figyelembevétele. Fontos tényezőnek tartják a vezetők továbbá a vállalati kultúrák hasonlóságát, valamint a tárgyalások alatti személyes benyomásokat.
Nyugat-európai, valamint amerikai vállalatvezetők azonban a fent említetteken túlmenően kvantifikált módszerekkel is igyekeznek alátámasztani döntéseiket, egyre népszerúbb az AHP használata, mely szintetizálni tudja a kvalitatív és a kvantitatív tényezőket egyaránt.

A módszer megismerése és egyre gyakoribb alkalmazása hatékonyabb döntéshozatalt biztosíthat a magyar szakemberek számára is.

\section{Felhasznált irodalom}

Szegedi Zoltán - Prezenszki József (2003): Logisztika menedzsment 340-342 o., Kossuth Kiadó

Bokor Zoltán (2004): Logisztikai szolgáltatók menedzsmentje és informatikája, Fơiskolai jegyzet

Saaty T. L. - Vargas L. G. (2001): Models, methods, concepts and applications of Analitical Hierarchy Process In: International Series in Operations Research and Management Sciences Boston /Dodrecht/London: Kluwer Academic Publishers

Tasan - Ozmehmet - Tuna (2005): Selection criteria for Logistics Service Providers In: E-conference proceedings 1st. International Conference on Business and Management Cesme, Turkey

Saaty, T. L. (1990): Decision making for leaders: the AHP for decisions in a complex world. In: RWS Publications, Pittsburgh, PA

Scott, C - Westbrook, R. (2000): New strategic tools for Supply Chain Management. In: International Journal of Physical Distribution and Logistic Management

Baumgarten, Walter (2000): Trends und Strategien In: Kurzkassung, Berlin

SULOGTRA - Effects on Transport of Trend sin Logistics and Supply Chain Management In: EU 5th FP, 2000-2002 